\title{
Familial hypercholesterolaemia in children and adolescents
}

${ }^{1}$ Małgorzata Myśliwiec, ${ }^{2}$ Mieczysław Walczak, ${ }^{3}$ Ewa Małecka-Tendera, ${ }^{4}$ Anna Dobrzańska, ${ }^{5}$ Barbara Cybulska, ${ }^{6}$ Krzysztof Filipiak, ${ }^{7}$ Artur Mazur, ${ }^{3}$ Przemysława Jarosz-Chobot, ${ }^{8}$ Agnieszka Szadkowska, ${ }^{9}$ Andrzej Rynkiewicz, ${ }^{10}$ Alicja Chybicka, ${ }^{11}$ Piotr Socha, ${ }^{1}$ Agnieszka Brandt, ${ }^{1}$ Joanna Bautembach-Minkowska, ${ }^{12}$ Tomasz Zdrojewski, ${ }^{13}$ Janusz Limon, ${ }^{14}$ Maciej Banach

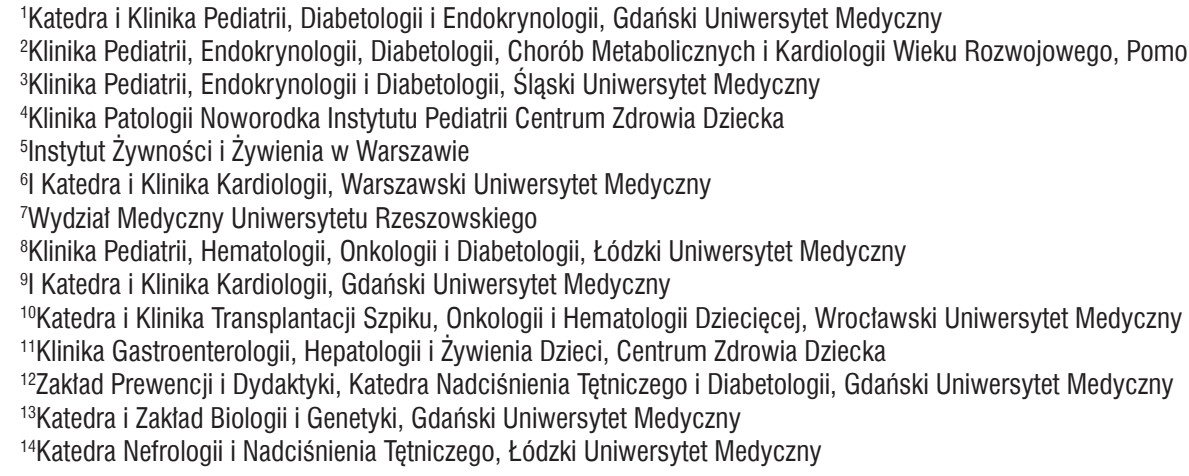

\section{Wstęp}

Hipercholesterolemia rodzinna (Familial Hypercholesterolemia, FH) jest jedną z lepiej poznanych chorób uwarunkowanych genetycznie, powodującą przyśpieszony rozwój miażdżycy oraz duże ryzyko wystąpienie incydentów sercowo-naczyniowych [1-3]. Miażdżyca w przebiegu FH rozwija się podstępnie i osiąga zaawansowany etap przed wystąpieniem objawów klinicznych $[4,5]$. FH jest chorobą o istotnym znaczeniu ekonomicz- nym dla społeczeństwa, w znaczący sposób ogranicza zdolność do pracy, a jej leczenie pochłania olbrzymie koszty. Śmiertelność z przyczyn sercowo-naczyniowych u osób z FH między 20 a 39 r.ż. jest 100-krotnie większa niż w populacji ogólnej [6]. Dzięki wczesnej identyfikacji osób z FH już w okresie dzieciństwa i wprowadzeniu efektywnej modyfikacji stylu życia i farmakoterapii można istotnie zmniejszyć częstość incydentów sercowonaczyniowych w życiu dorosłym i osiągnąc oczekiwaną dla populacji długość życia [7,8]. 
Niedostateczna diagnostyka i leczenie FH u dzieci $\mathrm{w}$ Polsce wskazują na potrzebę podniesienia poziomu świadomości i zrozumienia tej choroby zarówno w społeczeństwie, jak i w środowisku medycznym. Kluczowym punktem edukacji na temat FH jest zrozumienie znaczenia badań przesiewowych w populacji wieku rozwojowego oraz kaskadowego badania przesiewowego w rodzinach pacjentów, u których zdiagnozowano $\mathrm{FH}$.

Celem niniejszych rekomendacji jest przedstawienie bieżącej sytuacji epidemiologicznej, wytycznych rozpoznawania $\mathrm{FH}$ u dzieci i młodzieży w Polsce oraz możliwości ich skutecznego leczenia. Dokument ten stanowi uzupełnienie stanowiska Forum Ekspertów Lipidowych na temat FH u dorosłych [9].

\section{Epidemiologia i patogeneza hipercholesterolemii rodzinnej}

Hipercholesterolemia rodzinna jest najczęstszą chorobą monogenetyczną [1]. Ze względu na autosomalny dominujący sposób dziedziczenia wyróżnia się dwie postacie choroby: heterozygotyczną $(\mathrm{HeFH})$ i homozygotyczną (HoFH). Homozygotyczna postać FH występuje w populacji kaukaskiej z częstością jedno na milion żywych urodzeń, natomiast postać heterozygotyczna w krajach europejskich dotyczy średnio jednej osoby na 500 [6]. Szacuje się, że w Polsce obciążonych HeFH może być ponad 80 tys. osób. Wydaje się jednak, że wartość ta może być niedoszacowana.

Fenotyp hipercholesterolemii rodzinnej związany jest $\mathrm{z}$ mutacją jednego $\mathrm{z}$ trzech genów: genu receptora $L D L$ (opisano w niej około 1600 różnych mutacji), genu apolipoproteiny B (apo B) lub genu konwertazy proproteinowej subtiliziny/kexyny typ 9 (proprotein convertase subtilisin kexin 9, PCSK9) [10-12]. Mutacja genu receptora LDL dotyczy około 85-90\% pacjentów z FH. Nieprawidłowa struktura receptorów LDL albo Apo B, która jest dla nich ligandem, zaburza wiązanie się lipoprotein zawierających Apo B z receptorami. Skutkiem tego jest upośledzenie katabolizmu lipoprotein o niskiej gęstości w wątrobie $[13,14]$. W HeFH defekt dotyczy połowy receptorów LDL lub połowy cząsteczek Apo B. Trzecią niedawno wykrytą przyczyną rodzinnej hipercholesterolemii jest obecność mutacji genu PCSK9, która łączy się ze zwiększoną aktywnością degradacyjną tego białka (gain-of-function mutation) w stosunku do receptorów LDL. Jest ona stosunkowo rzadka, gdyż dotyczy mniej niż 5\% badanych $[12,15]$.

\section{Obraz kliniczny hipercholesterolemii rodzinnej u dzieci i młodzieży}

Postać heterozygotyczna hipercholesterolemii rodzinnej ma w populacji wieku rozwojowego często przebieg bezobjawowy. Średnie stężenie cholesterolu całkowitego w tej postaci wynosi od 300 $\mathrm{mg} / \mathrm{dl}(7,76 \mathrm{mmol} / \mathrm{l})$ do $500 \mathrm{mg} / \mathrm{dl}(12,93 \mathrm{mmol} / \mathrm{l})$ [6]. Rodzice i bliscy krewni są obciążeni przedwczesną chorobą wieńcową lub rozpoznaną hipercholesterolemią. W badaniu klinicznym u osób z tą postacią FH w 2-3 dekadzie życia można zaobserwować żółtaki w ścięgnach piętowych, zwłaszcza w ścięgnach Achillesa i ścięgnach prostowników ręki oraz rąbek starczy rogówki. Chociaż żółtaki są patognomoniczne dla tej choroby, to nie zawsze są obecne. Objawy kliniczne choroby wieńcowej występują na ogół w czwartej dekadzie życia [6].

W postaci hipercholesterolemii rodzinnej homozygotycznej praktycznie w ogóle nie stwierdza się aktywności receptora dla LDL, a stężenie cholesterolu całkowitego zazwyczaj wzrasta do 700$1200 \mathrm{mg} / \mathrm{dl}(18,1-31,03 \mathrm{mmol} / \mathrm{l})$ [6]. Podwyższony poziom cholesterolu stwierdza się już u noworodków. Żółtaki w skórze mogą tworzyć się w ciągu kilku pierwszych miesięcy, a w ścięgnach przyjmują postać guzowatą. Młodzi pacjenci z HoFH prezentują objawy choroby wieńcowej, rozsianej miażdżycy tętnic obwodowych, stenozy aortalnej oraz choroby naczyniowo-mózgowej. Na prawidłowe rozpoznanie choroby mogą naprowadzić zmiany w skórze i ścięgnach oraz obciążający wywiad rodzinny w kierunku przedwczesnej choroby sercowo-naczyniowej $[6,9]$.

\section{Zasady przeprowadzania badania gospodarki lipidowej u dzieci i młodzieży}

Stężenia cholesterolu całkowitego (total cholesterol, TC) w surowicy są niższe podczas życia wewnątrzmacicznego i po urodzeniu. Stężenie cholesterolu całkowitego i jego frakcji LDL-cholesterolu rośnie gwałtownie podczas pierwszego tygodnia życia dziecka, a następnie stopniowo do drugiego roku życia [16]. W następnych latach stężenia lipidów i lipoprotein utrzymują się na względnie stałym poziomie aż do okresu dojrzewania [16-18]. Podczas pokwitania stężenie cholesterolu LDL obniża się średnio o 15\% i można wtedy uzyskać wyniki fałszywie ujemne w kierunku diagnostyki FH $[19,20]$. Tak więc wiek pomiędzy 9 a 11 r.ż. jest 
najlepszym okresem do badań gospodarki lipidowej [16-18]. Jeśli w 9-11 roku życia stężenia lipidów są prawidłowe, badanie należy powtórzyć około 18 roku życia, gdyż wyniki lipidogramu uzyskane w tym wieku pozwalają najlepiej przewidzieć wartości lipidów w kolejnych dwóch dekadach życia [16-18]. Lekarze podstawowej opieki medycznej powinni być odpowiedzialni za przeprowadzenie badań przesiewowych (skrining uniwersalny) w kierunku zaburzeń lipidowych i ewentualne skierowanie pacjentów do poradni specjalistycznych zajmujących się zaburzeniami gospodarki lipidowej celem dalszej ich diagnostyki i leczenia. U dzieci rodziców z rozpoznaną $F H$ pierwsze oznaczenie lipidogramu należy przeprowadzić już pomiędzy 2 a 11 rokiem życia [16]. Badanie lipidogramu u dziecka powinno być wykonane w osoczu lub surowicy krwi żylnej pobranej na czczo, tj. co najmniej 9-12 godzin od ostatniego posiłku. Lipidogram powinien być wykonany dwukrotnie w odstępie 2-3 tygodni celem wyliczenia wartości średniej [19]. Jest to konieczne również ze względu na znaczne różnice w oznaczeniach, wynikające zarówno z przyczyn biologicznych, jak i laboratoryjnych. Profilu lipidowego nie powinno się badać wcześniej niż po trzech miesiącach od przebycia ostrej infekcyjnej choroby. Badanie polega na oznaczeniu w osoczu krwi żylnej cholesterolu całkowitego, triglicerydów i cholesterolu wysokiej gęstości (high density lipoprotein, HDL) oraz wyliczeniu frakcji cholesterolu LDL oraz cholesterolu nie - HDL [19].

\section{Kryteria rozpoznania FH u dzieci} i młodzieży

Według wytycznych Amerykańskiej Akademii Pediatrii [17] zaleca się ukierunkowane przesiewowe oznaczenia lipidów na czczo u:

- dzieci powyżej 2 roku życia, rodziców z rozpoznaną hipercholesterolemią rodzinną,

- dzieci powyżej 2 roku życia z trudnym do ustalenia wywiadem rodzinnym, u których stwierdzono inne czynniki ryzyka, takie jak: nadwaga - wskaźnik masy ciała (body mass index, BMI) $>85$. centyla (w Polsce > 90. centyla); otyłość - wskaźnik masy ciała (body mass index, BMI) $>95$.centyla (w Polsce > 97. centyla); wysokie optymalne (ciśnienie skurczowe i/lub rozkurczowe w 3 pomiarach $\geq 90$. centyla, ale $<95$. centyla dla wieku, wzrostu i płci); nadciśnienie tętnicze (ciśnienie skurczowe i/lub rozkurczowe w 3 pomiarach $\geq 95$. centyla dla wieku, wzrostu i płci); cukrzyca; mała aktywność fizyczna (<60 min dziennie),
Ostatnie rekomendacje National Lipid Association (NLA) oraz National Lipid Association Expert Panel on Familial Hypercholesterolemia zalecają wykonanie lipidogramu u wszystkich dzieci między 9 a 11 rokiem życia [16].

Kryteria rozpoznania dyslipidemii u dzieci nadal budzą wiele kontrowersji. Według zaleceń Raportu Programu Edukacji Cholesterolowej u Dzieci (National Education Cholesterol Program [NCEP] - Expert Panel on Blood Cholesterol Levels In Children and Adolescents) za graniczne stężenia cholesterolu całkowitego uznaje się wartości $\geq 170 \mathrm{mg} / \mathrm{dl}$ $(4,4 \mathrm{mmol} / \mathrm{l})$, a za nieprawidłowe $\geq 200 \mathrm{mg} / \mathrm{dl}(5,17$ $\mathrm{mmol} / \mathrm{l})$. Dla cholesterolu LDL wartości te wynoszą odpowiednio $\geq 110 \mathrm{mg} / \mathrm{dl}(2,84 \mathrm{mmol} / \mathrm{l}) \mathrm{i} \geq 130$ $\mathrm{mg} / \mathrm{dl}(3,36 \mathrm{mmol} / \mathrm{l})$ [19]. Populacja dziecięca ze stężeniem cholesterolu $\geq 240 \mathrm{mg} / \mathrm{dl}(6,21 \mathrm{mmol} / \mathrm{l})$ i cholesterolu $\mathrm{LDL} \geq 160 \mathrm{mg} / \mathrm{dl}(4,14 \mathrm{mmol} / \mathrm{l}) \mathrm{jest}$ w grupie zwiększonego ryzyka wykrycia heterozygotycznej postaci HF $[16,17]$.

Wartości pożądane, graniczne i wysokie dla lipoprotein, obecnie przyjęte dla dzieci i nastolatków, przedstawiono $\mathrm{w}$ tabeli I.

$\mathrm{W}$ rodzinach pacjentów ze zdiagnozowaną $\mathrm{FH}$ National Institute for Health and Clinical Excellence (NICE) oraz NLA Expert Panel on Familial Hypercholesterolemia zalecają tzw. skrining kaskadowy (cascade screening) [1, 16, 21]. Jest to pomiar stężenia cholesterolu frakcji LDL i/lub badania molekularne (jeżeli zidentyfikowano mutację u probanta) u członków rodzin pacjentów z rozpoznaną hipercholesterolemią rodzinną. Dotyczy to krewnych I stopnia, a jeżeli to możliwe - także II stopnia. Metoda ta umożliwia wykrycie nowych przypadków w populacji najwyższego ryzyka występowania FH. Oznaczenie stężenia lipidów w surowicy krwi u dzieci z rodzin obciążonych $\mathrm{FH}$ zaleca się nawet bezpośrednio po urodzeniu, ale zawsze przed 10 rokiem życia. Metoda ta jest bardziej czuła od skriningu cholesterolu LDL w całej populacji (skrining uniwersalny). Ujemną stroną skriningu kaskadowego w stosunku do skriningu uniwersalnego jest fakt, że można w nim pominąć dzieci $\mathrm{z}$ autosomalnie dominującą hipercholesterolemią, których rodzice są młodzi, bez objawów choroby sercowo-naczyniowej lub nieświadomi swoich wysokich stężeń cholesterolu [16].

Dla polskiej populacji pediatrycznej w wykrywaniu hipercholesterolemii rodzinnej najbardziej użyteczny jest schemat zaproponowany przez specjalistów z Wielkiej Brytanii (The Simon Broome Register Group) (tabela II), gdyż jako jedyny 
Tabela I. Wartości stężeń lipidów i lipoprotein w osoczu wg Panelu Ekspertów NCEP [19]. Punkty odcięcia dla wartości wysokich i niskich odpowiadają odpowiednio wartościom 95 i 75 centyla

\begin{tabular}{|l|l|l|l|}
\hline \multicolumn{1}{|c|}{ Kategoria } & \multicolumn{1}{c|}{$\begin{array}{c}\text { Stężenie } \\
\text { akceptowane }\end{array}$} & \multicolumn{1}{c|}{ Stężenie graniczne } & \multicolumn{1}{c|}{ Stężenie wysokie } \\
\hline TC $(\mathrm{mg} / \mathrm{dl}, \mathrm{mmol} / \mathrm{l})$ & $<170 / 4,4$ & $170-199(4,4-5,15)$ & $>200 / 5,17$ \\
LDL-C $(\mathrm{mg} / \mathrm{dl}, \mathrm{mmol} / \mathrm{l})$ & $<110 / 2,84$ & $110-129(2,84-3,34)$ & $\geq 130 / 3,36$ \\
Nie- $\mathrm{HDL}-\mathrm{C}(\mathrm{mg} / \mathrm{dl}, \mathrm{mmol} / \mathrm{l})$ & $<123 / 3,18$ & $123-143(3,18-3,7)$ & $\geq 144 / 3,72$ \\
Apo-B $(\mathrm{mg} / \mathrm{dl})$ & $<90$ & $90-109$ & $\geq 110$ \\
Triglicerydy (mg/dl, mmol/l) & & & \\
0-9 r.ż. & $<75 / 0,85$ & $75-99 / 0,85-1,12$ & $\geq 100 / 1,13$ \\
$10-19$ r.ż. & $<90 / 1,02$ & $90-129 / 1,02-1,46$ & $\geq 130 / 1,47$ \\
HDL-C $(\mathrm{mg} / \mathrm{dl}, \mathrm{mmol} / \mathrm{l})$ & $>45 / 1,16$ & $35-45 / 0,91-1,16$ & \\
\hline
\end{tabular}

Tabela II. Kryteria rozpoznawania hipercholesterolemii rodzinnej według Simon Broome Register Group

\begin{tabular}{|c|c|}
\hline Kryterium & Opis \\
\hline A & $\begin{array}{l}\text { Stężenie cholesterolu całkowitego } \\
>260 \mathrm{mg} / \mathrm{dl} \text { ( } 6,72 \mathrm{mmol} / \mathrm{l}) \text { (u osób < } 16 \text { roku życia), } \\
>290 \mathrm{mg} / \mathrm{dl}(7,50 \mathrm{mmol} / \mathrm{l}) \text { (u osób > } 16 \text { roku życia) } \\
\text { lub } \\
\text { stężenie LDL-cholesterolu } \\
>155 \mathrm{mg} / \mathrm{dl}(4,01 \mathrm{mmol} / \mathrm{l}) \text { (u osób < } 16 \text { roku życia), } \\
>190 \mathrm{mg} / \mathrm{dl}(4,91 \mathrm{mmol} / \mathrm{l}) \text { (u osób > } 16 \text { roku życia) }\end{array}$ \\
\hline B & Żółtaki u probanta lub krewnego I stopnia \\
\hline C & Obecność mutacji genu LDLR lub APOB \\
\hline D & $\begin{array}{l}\text { Zawał serca u krewnych I stopnia przed } 60 \text { rokiem życia lub krewnych II stopnia przed } 50 \\
\text { rokiem życia }\end{array}$ \\
\hline $\mathrm{E}$ & Stężenie cholesterolu całkowitego > $290 \mathrm{mg} / \mathrm{dl}(7,5 \mathrm{mmol} / \mathrm{l})$ u krewnego I lub II stopnia \\
\hline \multicolumn{2}{|l|}{ Rozpoznanie FH } \\
\hline Pewne & Kryteria A i B lub C \\
\hline Prawdopodobne & Kryteria A i D lub A i E \\
\hline
\end{tabular}

w kryteriach rozpoznania FH nie zawiera objawów klinicznych u probanta, które w postaci heterozygotycznej nie są obserwowane u dzieci [4, 22].

\section{Diagnostyka molekularna}

Jedyną uznaną w świecie metodą postawienia ostatecznego rozpoznania FH jest stwierdzenie mutacji w genie $L D L R$, Apo-B lub PCSK9 w badaniu molekularnym. Pomimo zwiększenia dostępności diagnostyki molekularnej w FH współczynnik wy- krywalności mutacji genów waha się od 30 do $80 \%$. Negatywny wynik badania genetycznego nie wyklucza rozpoznania $\mathrm{FH}$. Badanie genetyczne przeprowadzone zostaje na materiale genetycznym wyizolowanym z krwi pacjenta, pobranej do probówek z EDTA. Jeśli w rodzinie potwierdzono obecność mutacji genu LDLR lub APOB, u dzieci można go uzyskać również z wymazu $\mathrm{z}$ jamy ustnej.

Zawsze w przypadkach wątpliwych, jeśli tylko pozwalają na to środki finansowe, zaleca się potwierdzenie diagnozy FH metodami genetycznymi. 


\section{Różnicowanie hipercholesterolemii rodzinnej}

Liczne czynniki wpływają na podwyższenie stężenia cholesterolu całkowitego i jego frakcji LDL. Profil lipidowy u osób z FH może być podobny do spotykanego $\mathrm{w}$ hipercholesterolemii wtórnej w przebiegu licznych chorób: niedoczynności tarczycy, zespołu nerczycowego, cukrzycy, zespołu Cushinga, porfirii oraz podczas przewlekłej terapii niektórymi lekami, takimi jak: diuretyki tiazydowe i pętlowe, kortykosteroidy, cyklosporyna, estrogeny, progestageny, inhibitory proteazy $[23,24]$. Wykrycie wtórnych przyczyn hipercholesterolemii pozwala istotnie zmniejszyć liczbę dzieci z podejrzeniem FH.

W różnicowaniu podwyższonego stężenia cholesterolu całkowitego i LDL-C, szczególnie u pacjentów z nadwagą i otyłością, należy wziąć również pod uwagę rodzinną mieszaną hiperlipidemię $(\mathrm{Fa}$ milial Combined Hyperlipidemia, FCH). U dzieci z FCH stwierdza się podwyższone poziomy triglicerydów, niskie stężenia HDL-C przy prawidłowych, granicznych lub podwyższonych stężeniach cholesterolu LDL. To zaburzenie lipidowe może być potęgowane wspótistniejącą nadwagą i otyłością i zazwyczaj związane jest $\mathrm{z}$ insulinoopornością $[19,25,26]$. Dlatego przy utrzymywaniu się dyslipidemii ze stężeniem cholesterolu LDL $\geq 130 \mathrm{mg} / \mathrm{dl}$ $(3,36 \mathrm{mmol} / \mathrm{l})$ po zmniejszeniu masy ciała u pacjentów $\mathrm{z}$ nadwagą i otyłością i z dodatnim wywiadem rodzinnym w kierunku przedwczesnej choroby sercowo-naczyniowej należy rozważyć diagnostykę w kierunku FH $[19,25]$. Niestety w chwili obecnej nie udało się wyizolować żadnej mutacji odpowiedzialnej za zaburzenia występujące u pacjentów z FCH, co znacznie ułatwiłoby różnicowanie w przypadkach wątpliwych ze względu na coraz szerszy dostęp do badań molekularnych.

\section{Leczenie hipercholesterolemii rodzinnej u dzieci i młodzieży}

Postawienie rozpoznania $\mathrm{FH}$ jest wskazaniem do objęcia opieką lekarską całej rodziny, edukacji pacjenta, wprowadzenia zaleceń dietetycznych i leczenia farmakologicznego. Opiekę sprawować powinien zespół złożony z lekarzy specjalistów (pediatry diabetologa i/lub endokrynologa, lipidologa i genetyka) pielęgniarki, dietetyka i psychologa. Należy z naciskiem podkreślić, że w systemie polskiej opieki zdrowotnej nadal nie funkcjonują wy- odrębnione poradnie lipidowe, a leczenie zaburzeń lipidowych odbywa się $\mathrm{w}$ poradniach diabetologicznych, zaburzeń metabolicznych lub kardiologicznych.

Celem leczenia FH u dzieci jest redukcja stężenia cholesterolu LDL $0>=\mathbf{5 0} \%$ lub utrzymanie stężeń LDL- cholesterolu $<130 \mathrm{mg} / \mathrm{dl}(3,36$ mmol/l), a u dzieci ze wspólistniejącą cukrzycą $<\mathbf{1 0 0} \mathbf{~ m g} /$ dl $(\mathbf{2 , 5 9} \mathbf{~ m m o l} / \mathrm{l})[16,21]$.

\section{Edukacja chorych}

Edukacja chorych to coraz bardziej doceniany i coraz lepiej poznany czynnik, który może istotnie wpłynąć na uzyskanie pozytywnych efektów terapeutycznych. Pacjent powinien otrzymać szczegółowe informacje na temat przyczyn FH i jej związku z przedwczesną chorobą wieńcową, dodatkowych czynników ryzyka choroby wieńcowej, możliwości i konieczności ich modyfikacji, sposobów leczenia oraz powikłań FH

\section{Leczenie dietetyczne}

W zaleceniach Zespołu Ekspertów NCEP zakwestionowano konieczność 6-12-miesięcznego okresu stosowania diety niskocholesterolowej przed rozpoczęciem farmakoterapii u dzieci z rozpoznaną FH. Eksperci podkreślili jednak istotną rolę leczenia dietetycznego jako leczenia wspomagającego u każdego dziecka z dyslipidemią [19].

Panel pediatryczny NCEP rekomenduje włączenie diety leczniczej powyżej 2 roku życia, niemniej dane $\mathrm{z}$ badania STRIP (The Special Turku Coronary Risk Factor Intervention Project) i DISC (Dietary Intervention Study In Children) wykazują, że niskotłuszczowa dieta może być bezpiecznie włączona u dzieci już od 7 miesiąca życia, jeśli jest prowadzona pod kontrolą lekarską [27]. Forum Ekspertów Lipidowych w Polsce przychyla się do rekomendacji NCEP dotyczącej włączenia leczenia dietetycznego od 2 roku życia, a w pilnych przypadkach nawet wcześniej, jeżeli jest prowadzone pod ścisłą kontrolą lekarską.

U dzieci starszych powinno się przestrzegać rekomendacji żywienia dzieci, opracowanych przez ekspertów Amerykańskiej Akademii Pediatrii, i zastosować dietę leczniczą [17, 28]. Polega ona głównie na ograniczeniu spożycia nasyconych kwasów tłuszczowych do $<7 \%$ ogółu energii i cholesterolu pokarmowego $<200 \mathrm{mg} /$ dobę $[4,17,19]$. Podkreśla się istotną rolę w diecie substancji takich, jak błon- 
nik oraz roślinne sterole i stanole, a także zaleca się spożywanie tłustych ryb morskich. Porad żywieniowych powinien udzielić dietetyk.

Skuteczność diety niskotłuszczowej w leczeniu FH jest ograniczona. Zastąpienie tłuszczów nasyconych wielonienasyconymi może doprowadzić do obniżenia stężenia cholesterolu frakcji LDL jedynie o 15\%. Dlatego w leczeniu FH konieczne jest wdrożenie farmakoterapii.

\section{Leczenie farmakologiczne}

Wprowadzenie wczesnej terapii hipolipemizującej u osób z rozpoznaną FH w znacznym stopniu zmniejsza częstość występowania choroby wieńcowej, zawałów serca, konieczności wykonania zabiegów rewaskularyzacji naczyń, a także przedwczesnych zgonów sercowo-naczyniowych [29]. Lekami pierwszego wyboru w leczeniu FH są statyny [4, $17,23,24,30]$, czyli inhibitory reduktazy 3-hydroksy-3-metylo-glutarylo-koenzymu A (HMG-CoA). Udział zalecanych wcześniej preparatów w leczeniu FH u dzieci, tj. fibratów czy cholestyraminy, został znacznie ograniczony ze względu na brak rzetelnych badań potwierdzających ich skuteczność $[23,30]$.

Należy podkreślić, że dane na temat stosowania leków hipolipemizujących u dzieci są ograniczone i dotyczą jedynie krótkotrwałych interwencji, nie uwzględniając długofalowej tolerancji i bezpieczeństwa leków [31-33].

Obecnie rekomendowany wiek przez NLA Expert Panel on Familial Hypercholesterolemia, w którym można rozważyć wprowadzenie statyn do leczenia FH u dzieci, to 8 rok życia [16, 21]. Przed zakwalifikowaniem dziecka z FH do leczenia farmakologicznego należy wziąć pod uwagę, oprócz wieku, płeć, dokładny wywiad rodzinny, czynniki ryzyka (tj. stany uszkodzenia mięśni, choroby wątroby, nerek, układu nerwowego, ciężkie infekcje, zaburzenia metaboliczne, hormonalne, elektrolitowe) i wynik badania dopplerowskiego oceniający grubość wewnętrznej i środkowej błony tętnicy szyjnej (IMT).

Farmakoterapia zalecana jest:

- przy poziomie cholesterolu $\mathrm{LDL} \geq 130 \mathrm{mg} / \mathrm{dl}$ $(2,59 \mathrm{mmol} / \mathrm{l}) \mathrm{u}$ dzieci z cukrzycą,

- przy poziomie cholesterolu $\mathrm{LDL} \geq 160 \mathrm{mg} / \mathrm{dl}$ $(4,14 \mathrm{mmol} / \mathrm{l}) \mathrm{u}$ dzieci z przynajmniej dwoma czynnikami ryzyka chorób układu sercowo-naczyniowego (tj. otyłość, nadciśnienie tętnicze, palenie tytoniu) lub z obciążonym wywiadem rodzinnym w kierunku wczesnego występowania chorób układu krążenia,

- przy poziomie cholesterolu LDL $\geq 190 \mathrm{mg} / \mathrm{dl}$ (4,91 mmol/l) u dzieci bez czynników ryzyka.

U dzieci poniżej 8 roku życia wprowadzenie leków jest uzasadnione przy poziomie $\mathrm{LDL}>500$ $\mathrm{mg} / \mathrm{dl}(12,93 \mathrm{mmol} / \mathrm{l}), \mathrm{np}$. w przebiegu homozygotycznej postaci $\mathbf{F H}[16,21]$.

Niestety powyższe poziomy cholesterolu LDL wyznaczone są arbitralnie. Nie przeprowadzono dotąd rzetelnych badań w populacji dziecięcej, pozwalających na wiarygodne określenie poziomu LDL-cholesterolu, powyżej którego znacząco wzrasta ryzyko rozwoju wczesnej miażdżycy naczyń. Co więcej, nie znamy także tzw. bezpiecznego poziomu cholesterolu LDL, który chroni przed rozwojem powikłań sercowo-naczyniowych. Obecne zalecenia oparte są na ekstrapolacji danych z badań przeprowadzonych w populacji dorosłych [30, 31]. Zawsze należy zbilansować leczenie hipolipemizujące u dzieci pomiędzy określoną dawką leku a potencjalnymi efektami ubocznymi stosowanej terapii.

\section{Ogólne zasady stosowania statyn}

Statyny różnią się między sobą siłą działania w stosunku do dawki. Podaje się je zwykle jednorazowo wieczorem, ponieważ fizjologicznie w godzinach nocnych zwiększona jest synteza cholesterolu. Leczenie dzieci z FH rozpoczyna się od małych dawek statyn (2,5-5-10 mg/dobę w zależności od preparatu) i powoli zwiększa się dawkę aż do osiągnięcia zamierzonego efektu terapeutycznego. Pełen efekt działania statyn na gospodarkę lipidową obserwuje się po 6 tygodniach. Obniżenie stężenia cholesterolu LDL osiągnięte po 2 tygodniach stosowania odpowiedniej dawki statyny zazwyczaj odpowiada $90 \%$ działania tej dawki $[16,21,31,32]$.

Przed rozpoczęciem leczenia statynami należy wykonać oznaczenie aktywności aminotransferaz, w szczególności ALT oraz kinazy kreatynowej (creatinine kinase, CK). Aminotransferazy należy skontrolować po 6 tygodniach od włączenia statyny, a następnie badać co 6 miesięcy w kolejnych latach. W przypadku 3-krotnego lub większego wzrostu poziomu aminotransferaz powyżej górnej granicy normy należy statynę odstawić [2]. Podwyższenie stężenia aminotransferaz jest zwykle przemijające i ustępuje po 2-3 miesiącach od odstawienia leku [31-33].

Obecnie nie zaleca się rutynowego oznaczania aktywności CK w czasie leczenie tylko w razie wy- 
stąpienia dolegliwości mięśniowych, tj. miopatii (bóle mięśniowe i/lub osłabienie mięśni). Jeśli CK przekracza 5-krotność górnej granicy normy, leczenie statyną należy przerwać [33].

Do innych działań ubocznych statyn należą: zaburzenia żołąkowo-jelitowe, uczucie zmęczenia, bezsenność, bóle głowy, osutki skórne, neuropatia obwodowa, zespół toczniopodobny, występują one jednak bardzo rzadko.

Po rozpoczęciu terapii u dzieci należy regularnie oceniać poziom cholesterolu oraz monitorować działania niepożądane leków, wpływające na rozwój dziecka, stan jego odżywienia, stopień dojrzałości płciowej [30].

Do przeciwskazań do podawania statyn u dzieci należą: nadwrażliwość na lek, stany uszkodzenia mięśni, miopatia $\mathrm{w}$ związku $\mathrm{z}$ podawaniem statyn, aktywna choroba miąższu wątroby lub utrzymująca się wysoka aktywność aminotransferaz, wzrost poziomu aminotransferaz 3-krotnie powyżej górnej granicy normy w trakcie podawania statyn, niewydolność nerek, ciężkie infekcje, poważne zabiegi operacyjne, duże urazy, poważne zaburzenia metaboliczne, hormonalne, elektrolitowe, niekontrolowane napady padaczki.

Obecnie statyny są najsilniejszymi dostępnymi lekami hipolipemizującymi w leczeniu $\mathrm{FH}$, ale nie zawsze stosowane w monoterapii pozwalają na uzyskanie docelowych stężeń cholesterolu LDL.

\section{Żywice wiążące kwasy żółciowe}

Żywice powodują zmniejszenie stężenia cholesterolu frakcji LDL o $10-30 \%$. Jednak ze względu na dużą objętość dawki oraz uciążliwe objawy uboczne ze strony przewodu pokarmowego, między innymi zaparcia, nie są one szeroko stosowane u dzieci [31-33]. Dość dobrze tolerowanym lekiem z grupy żywic jest Colesevelam (kolesewelam, Welchol). Został on zatwierdzony w USA do leczenia heterozygotycznej rodzinnej postaci hypercholesterolemii u dzieci. W Polsce jego stosowanie jest marginalne.

\section{Ezetimib}

Ezetimib jest lekiem hamującym wchłanianie cholesterolu ze światła jelita cienkiego na poziomie błony komórkowej enterocytów i białek wiążących sterole. Ze względu na różne punkty działania ezetimibu i statyn dodanie $10 \mathrm{mg} /$ dobę ezetimibu do statyny powoduje obniżenie stężenia cholesterolu LDL o kolejne 15-25\%. Pełne działanie hipolipemizujące ezetemibu osiąga się już po 2 tygodniach jego stosowania [17]. Należy go ostrożnie używać u pacjentów w zaburzeniami funkcji wątroby i zespołach złego wchłaniania. U dzieci Amerykańska Akademia Pediatrii dopuszcza warunkowo zastosowanie Ezetimibu w przypadku nietolerancji leczenia statynami [17]. Lek ten nierzadko jest cennym uzupełnieniem terapii FH w Polsce, szczególnie, że jest on refundowany (30\% odpłatności) w tej grupie pacjentów.

\section{Podsumowanie}

Hipercholesterolemia rodzinna jest względnie częstym zaburzeniem lipidowym, jednak obecnie wciąż dość rzadko rozpoznawanym lub niewłaściwie leczonym. Szacuje się, że FH jest zdiagnozowana tylko u około $20 \%$ społeczeństwa, a wśród nich tylko nieliczna liczba pacjentów otrzymuje odpowiednie leczenie w Polsce. FH charakteryzują znacznie podwyższone stężenia cholesterolu LDL występujące od urodzenia. Czynnościowe i morfologiczne zmiany ścian naczyniowych w przebiegu FH obserwuje sie już u dzieci. Choroba ta przyczynia się to do szybkiego rozwoju miażdżycy oraz przedwczesnej choroby wieńcowej i śmiertelności. Wczesna diagnoza i odpowiednie leczenie FH zastosowane $\mathrm{w}$ populacji wieku rozwojowego może znacznie zmniejszyć ryzyko rozwoju chorób sercowo-naczyniowych i nagłego zgonu u osób dorosłych. Lekarze podstawowej opieki zdrowotnej powinni być świadomi swej kluczowej roli we wczesnym wykrywaniu i leczeniu FH oraz konieczności kierowania do specjalistów z zakresu zaburzeń lipidowych. Badania przesiewowe gospodarki lipidowej w ogólnej populacji dzieci w wieku 9-11 lat oraz badania kaskadowe w rodzinach obciążonych $\mathrm{FH}$ mogą znacznie przełożyć się na zmniejszenie kosztów leczenia powikłań związanych z nieleczoną hipercholesterolemią. Finansowanie wykrywania, leczenia, edukacji i badań naukowych dotyczących FH powinno pochodzić $\mathrm{z}$ wielu źródeł, włączając w te Narodowy Fundusz Zdrowia, instytucje rządowe, naukowe oraz przemysł farmaceutyczny.

Przedstawione stanowisko opracowało grono polskich ekspertów w odniesieniu do dzieci i młodzieży z hipercholesterolemią rodzinną. Z chwilą osiągnięcia dojrzałości należy kierować się wskazaniami do leczenia FH dla dorosłych, w tym opracowanymi niedawno zaleceniami polskich autorów [34]. 


\section{PIŚMIENNICTWO/REFERENCES}

[1] Wierzbicki A.S., Humphries S.E., Minhas R.: On behalf of the Guideline Development Group. Familial hypercholesterolaemia: summary of NICE guidance. BMJ, 2008:337, a1095.

[2] Reiner Ž., Catapano A.L., De Backer G. et al.: ESC/EAS guidelines for management of dyslipidemias of the European Society of Cardiology (ESC) and the European Atherosclerosis Society (EAS). Eur. Heart. J., 2011:32, 1769-1818.

[3] Austin M.A., Hutter C.M., Zimmern R.L. et al.: Familial hypercholesterolemia and coronary heart disease: a HuGE association review. American Journal of Epidemiology, 2004:160, 421-429.

[4] Expert Panel Integrated Guidelines for Cardiovascular Health and Risk Management: Summary Report. Pediatrics, 2011:128, 212258.

[5] Juonala M., Vikari J.S., Rönnemaa T. et al.: Associations of dyslipidemias from childhood to adulthood with carotid intima-media thickness, elasticity, and bravhial flowmediated dilatation in adulthood: the Cardiovascular Risk in Young Finns Study. Arterioscler. Thromb. Vasc. Biol., 2008:28(5), 1012-1017.

[6] Familial Hypercholesterolemia. A Report of a WHO consultation. WHO. Geneva, Switzerland, 1998.

[7] Neil A., Cooper J., Betteridge J. et al.: Reductions in all-cause, cancer and coronary mortality in statin-treated patients with heterozygous hypercholesterolemia: a prospective registry study. Eur. Heart J., 2008:29, 2625-2633.

[8] Pijman A.H., Huijgen R., Verhagen S.N. et al.: Evaluation of cholesterol lowering treatment of patients with familial hypercholesterolemia: a large cross-sectional study in The Netherlands. Atherosclerosis, 2010:209, 189-94.

[9] Rynkiewicz A., Cybulska B., Banach M. et al.: Management of familial heterozygous hypercholesterolemia: Position Paper of the Polish Lipid Expert Forum. J. Clin. Lipidol., 2013:7(3), 217-221.

[10] Innerarity T.L., Weisgraber K.H., Arnold K.S. et al.: Familial defective apolipoprotein B-100: low density lipoproteins with abnormal receptor binding. Proc. Natl. Acad. Sci. U S A, 1987:84, 6919-6923.

[11] Abifadel M., Varret M., Rab J.P. et al.: Mutations in PCSK9 cause autosomal dominant hypercholesterolemia. Nat. Genet., 2003:34, $154-156$.

[12] Abifadel M., Rabes J.P., Devillers M. et al.: Mutations and Polymorphisms in the Proprotein Convertase Subtilin Kexin 9 (PCSK9) Gene in Cholesterol Metabolism and Disease. Human Mutation, 2009:30, 520-529.

[13] Varret M., Abifadel M., Rabes J.P. et al.: Genetic heterogeneity of autosomal dominant hypercholesterolemia. Clin. Gen., 2008:78, $1-13$.

[14] Chmara M., Wasag B., Żuk J. et al.: Molecular characterization of Polish patients with familial hypercholesterolemia: novel and recurrent LDLR mutations. Appl. Genet., 2010:51(1), 95-106.

[15] Huang C.C., Fornage M., Lloyd-Jones D.M. et al.: Longitudinal Association of PCSK9 Sequence Variations with Low-Density Lipoprotein Cholesterol Levels The Coronary Artery Risk Development in Young Adults Study. Circ. Cardiovasc. Genet., 2009:2, 354361.

[16] Goldberg A.C., Hopkins P.N., Toth P.P. et al.: Familial Hypercholesterolemia: Screening, diagnosis and management of pediatric and adult patients. Clinical guidance from the National Lipid Association Expert Panel on Familial Hypercholesterolemia. Journal of Clinical Lipidology, 2011:5, 133-140.

[17] Daniels S.R., Greer F.R. and the Committee on Nutrition: Lipid screening and cardiovascular health in childhood. Pediatrics, 2008: 122, 198-208.

[18] National Cholesterol Education Program: Report of the Expert Panel on Blood Cholesterol Levels in Children and Adolescents. Pediatrics, 1992:89, 525-584.

[19] Kwiterovich P.O.J.: Recognition and management of dyslipidemia in children and adolescents. J. Clin. Endocrinol. Metab., 2008: 93(11), 4200-4209.

[20] Jolliffe C.J., Janssen I.: Distribution of lipoproteins by age and gender in adolescents. Irculation 2006:114(10), 1056-1062.

[21] Daniels S.R., Gidding S.S., de Ferranti S.D.: Pediatric aspects of Familial Hypercholesterolemias: Recommendations from the National Lipid association Expert panel on Familial Hypercholesterolemia. Journal of Clinical Lipidology, 2011:5, 30-37.

[22] Marks D., Thorogood M., Neil H.A. et al.: A review on the diagnosis, natural history, and treatment of familial hypercholesterolemia. Atherosclerosis, 2003:168(1), 1-14.

[23] Reiner Ž., Catapano A.L., De Backer G. et al.: ESC/EAS guidelines for management of dyslipidemias of the European Society of Cardiology (ESC) and the European Atherosclerosis Society (EAS). Eur. Heart J., 2011:32, 1769-1818.

[24] Ito M.K., McGowan M.P., Moriaty P.M.: Management of familial hyperlipidemias in adult patients. Recommendations from National Lipid Association Expert Panel of Familial Hypercholesterolemia. J. Clin. Lipidol., 2011:5, 38-45.

[25] Lifshitz F.: Obesity in children. J. Clin. Res. Pediatr. Endocrinol., 2008:1(2), 53-60.

[26] Freedman D.S., Mei Z., Srinivasan S.R. et al.: Cardiovascular risk factor and excess adiposity among overweight children and adolescents: the Bogalusa Heart Study. J. Pediatr., 2007:150(1), 12-17.

[27] Simell 0., Niinikoski H., Rönnemaa T. et al.: Special Turku Coronary Risk Factor Intervention Project for Babies (STRIP). Am. J. Clin. Nutr., 2000:72(5), 1316-1331.

[28] American Academy of Pediatrics, Committee on Nutrition. Cholesterol in childhood. Pediatrics, 1998:101, 141-147. 
[29] Ballantyne C.M., O'Keefe J.J.H., Gotto A.M.: Dyslipidemia Essentials. Royal Oak, Michigan: Physicians Press, 2005, 98-123.

[30] O'Gorman C.S.M., O'Neill M.B.O., Conwell L.S.: Considering statins for cholesterol-reduction In children if lifestyle and diet changes do not improve their health: a review of the risks and benefits. Vasc. Health Risk Manag., 2011:7, 1-14.

[31] Avis H.J., Vissers M.N., Stein E.A. et al.: A systematic review and meta-analysis of statin therapy in children with familial hypercholesterolemia. Arterioscler. Thromb. Vasc. Biol., 2007:27, 1803-1810.

[32] Arambepola C., Farmer A.J., Perera R. et al.: Statin treatment for children and adolescents with heterozygous familial hypercholesterolaemia: A systematic review and meta-analysis. Atherosclerosis, 2007:195, 339-347.

[33] Wiegman A., Hutten B.A., De Groot E. et al.: Efficacy and safety of statin therapy in children with familial hypercholesterolemia. A randomized controlled trial. Jama, 2004: 292(3), 331-337.

[34] Rynkiewicz A., Cybulska B., Banach M. et al.: Management of familial heterozygous hypercholesterolaemia. Position paper of the Polish Lipid Expert Forum. Kardiol. Pol., 2013:71(1), 107-111. 